\title{
Without Environmental Justice, the Renewable Energy Transition Will Leave Low- Income and BIPOC Communities Behind
}

\section{Carolyn E. Ramírez}

Northwestern University, Department of Chemical and Biological Engineering, Evanston, IL https://doi.org/10.38126/ISPG180306

Corresponding Author: CRamirez@u.northwestern.edu

Keywords: environmental justice; climate change; energy equity; renewable energy

Executive Summary: As extreme weather events become more common in the United States due to the worsening effects of climate change, access to utilities like electricity and water will be continually strained. Blackouts and intermittent utility interruptions impact low-income and communities of color most negatively. While renewable energy technologies promise alleviation of emissions and pollution, high cost and a lack of equitable energy infrastructure make it harder for low-income and communities of color to access renewable energy benefits. I propose a series of policies to address the cost barriers of renewable energy, improve reliability and access to power grids, and standardize household weatherization for people from all communities.

\section{Introduction}

On Sunday, February 14th, 2021, the Texas power grid failed. As a rare, but not unprecedented, winter storm rolled through the state, pipes burst, gas lines froze, lights and heaters shut off. At least 194 people died (Despart et al. 2021). Many boil-water notices remained in place throughout the state until the end of the month, and the damage from broken water mains, flooded apartments and homes, and a lack of electricity left the region in a state of recovery as if a hurricane had just rolled through. The roads remained unusable for a week because the state had little road salt and very few plows. Even some hospitals lost power and water (Jervis 2021). Additionally, several months later, many Texans are still dealing with sky-high utility bills from the week of the storm. A similar storm caused rampant blackouts in the state in 2011, but mitigation recommendations were largely ignored (Price and Sechler 2021).

While this sort of unreliable power and price gouging is incomprehensible to many Americans, it is not new to people of color or people in lowincome communities. Black, Indigenous, and people of color (BIPOC) deal with larger proportionate energy bills and more frequent blackouts due to less reliable electricity (Franklin et al. 2017, Drehobl and Ross 2016). The root of this issue is a long history of racist housing policies in the United States that led to profound disparities in the health and safety of different communities. The main lesson policymakers should take from the Texas blackouts is that our energy grid needs urgent upgrades that center marginalized communities. Otherwise, racial disparities in energy access will continue to grow.

Energy and environmental justice entered national and local science policy discourse over the last few decades following the advent of our modern understanding of anthropogenic climate change in the 1950s and the beginning of the environmental justice movement in the 1980s (History.com Editors 2017; EPA 2021; Skelton and Miller 2016). Modern science policy looks different than postWorld War II when Vannevar Bush penned Science, The Endless Frontier. Policy priorities in post-war times focused on fighting disease, increasing funding to university research, and recruiting more talented scientists (Bush 1945). These pillars are relevant today in different contexts, but Bush did 
not include environmental issues or racial inequities as policy concerns in 1945.

My proposed energy policy centers on environmental justice to fill in gaps from Science, The Endless Frontier. This policy is twofold: 1) reform the U.S. energy grid by focusing on improving energy infrastructure for BIPOC communities, providing government mechanisms to protect Americans from predatory utility companies, and implementing disaster-preparedness to prevent blackouts; and 2) face climate change head-on by transitioning to cleaner, renewable energy sources as soon as possible. Transitioning to renewable energy to address climate change without any changes to both the U.S. electric grid and utility structure will result in BIPOC communities still losing.

\section{i. Racist legacies tilt climate change against BIPOC communities}

The creation of the Federal Housing Administration (FHA) in 1934 federally formalized racial discrimination in loan lending for property purchase. The FHA perpetuated a policy known as "redlining" which created white-only neighborhoods because only white families could get loans from the FHA (Madrigal 2014). From 1934 to 1968, 98\% of all loans the FHA awarded were given to white families (Fulwood III 2016). This drastic gap in property ownership between white and Black families is a large contributor to the racial wealth gap due to differences in generational wealth. These racist housing laws also continue to impact Latino/ $\mathrm{x}$, Asian, and Native American families. Decreased wealth for BIPOC families combined with a historic lack of geographic mobility results in rural and suburban communities being mostly white while cities are mostly non-white (Parker et al. 2018). Consequently, BIPOC communities are exposed to more pollution from industry and vehicle exhaust due to living in communities that border or are otherwise closer to industry and more concentrated emissions than white people (UCS 2019; Fleischman and Franklin 2017).

The resounding evidence that fossil fuel pollution and climate change disproportionately impact BIPOC communities should indicate that they have the most to gain from transitioning to renewable energy technologies and eliminating fossil fuel pollution. However, without an electric grid upgrade and changes in our utility infrastructure, renewable energy technologies like solar cells could increase the utility burden on BIPOC and low-income communities while also not remedying the lack of reliable electricity. People of color are more likely than white people to suffer from energy poverty, or inefficient utility infrastructure in their homes, which results in these households paying a larger portion of their income on utility bills ("EJTRJ" 2020; Mock 2019). Energy poverty has not been acknowledged by the U.S. government as a national crisis despite its consequences for BIPOC and low-income communities (Bednar and Reames 2020). Renewable energy resources are expensive to install and can be intermittent energy suppliers without appropriate infrastructure, such as reliable storage and proper insulation (Thompson 2019). Without implementing rigorous new energy policies at all levels of government, BIPOC communities could wind up hurting more during the renewable energy transition.

\section{ii. National progress on renewable energy and climate policy}

With the beginning of the Biden administration in January of 2021, climate change became a central issue to American policy. On February 19th, 2021, the United States officially rejoined the Paris Agreement (Blinken 2021). President Biden and Vice President Harris have a climate plan that involves making the U.S. run on $100 \%$ clean carbon-neutral energy by 2050 (Murphy 2021). A week into the new administration, President Biden signed a series of executive orders that centered climate change domestically and internationally, established new cabinet positions and committees focused on climate, eliminated fossil fuel subsidies, established intent to create new union jobs in clean energy, ended new oil and gas leases on public lands, and committed to center environmental justice in energy policy (The White House 2021).

Notably, President Biden has not signed onto the Green New Deal (GND), introduced to Congress in 2018 by Representative Alexandria Ocasio-Cortez and Senator Edward J. Markey (Ocasio-Cortez 2019). The GND is a broad congressional resolution including many goals to divest the U.S. from fossil 
fuels, be carbon-neutral, and run on $100 \%$ clean energy by 2050 (similar to Biden's plan). The GND is more far-reaching than Biden's plan, detailing a more aggressive timeline to eliminate all fossil fuel usage in the U.S., and also includes more universal job and healthcare promises (Berardelli 2020). Regardless of these differences, the Biden administration presents an opportunity to enact impactful environmental justice policy to alleviate climate burdens on underserved communities, although the currently polarized and relatively moderate political climate suggests passing effective climate legislation will be challenging.

\section{iii. Renewables are competitive, but dominant} companies resemble big oil

While fossil fuels still dominate energy usage in the U.S., renewables have quickly gained ground (Desilver 2020). The International Energy Agency declared last year that solar is the "cheapest ... electricity in history" (Evans 2020). This development does not come as a surprise to many renewable energy companies who have been quietly growing in wealth and power over the last few decades. NextEra Energy is one of those skyrocketing corporations, challenging oil giants like ExxonMobil by increasing their market capitalization sixfold in the last decade (Blunt and McFarlane 2020). While the success of renewable energy companies is great news for the transition to sustainable technologies, the prospect of multibillion-dollar corporations controlling energy access across the country (and world) poses a risk of continued limited energy access and reliability for millions of Americans in BIPOC and low-income communities.

Large oil companies like ExxonMobil have a long history of prioritizing profits over people, highlighted by their denial of climate change over the last four decades (Lavelle 2019). Exxon, the American Petroleum Institute, and others formed the Global Climate Coalition (GCC) in 1989 to push pseudoscience around climate change and refute evidence that fossil fuel usage was contributing to climate change. They successfully lobbied the George W. Bush Administration to back out of the Kyoto Protocol (Banerjee et al. 2015; Hasemyer and Cushman 2015). The massive influence that multi-billion-dollar corporations have on the national energy landscape repeatedly puts corporate profits and prosperity over environmental justice interests. While renewable energy means deploying clean, carbon-neutral energy sources, there is still a risk of corporate greed hurting the most marginalized communities.

To date, there are many laws and statutes in place that regulate energy efficiency, set standards for carbon emissions reduction, and mandate integration of biofuels at both the federal and state levels (EIA 2021). However, one of the only laws that protects consumers from predatory utility companies is the Public Utility Holding Company Act of 1935, which prevents utility companies from forming a monopoly (UCS 2002). The Federal Energy Regulatory Commission, which oversees electric transmission nationally, also has statutes in place that require utility companies to provide equal energy access to consumers (Sundback et al. 2020). These regulations are non-specific and do not correct for systemic racism in housing and energy poverty. As the national energy landscape evolves and environmental justice drives policy changes, utility regulations need to be rewritten to center improvement in energy access and quality for BIPOC and low-income communities.

\section{Policy recommendations}

\section{i. Recommendation 1: Need for consumer protections and utility weatherization upgrades} The general lack of updated and effective utility regulations allows systemic racism to perpetuate in housing and energy access. As evidenced by the destruction from annual natural disasters like the recent winter storm in Texas and hurricanes in the Gulf and on the East coast, our electric grids are not protected well enough to continue to provide vital power access (Ferman 2021). The free market model without adequate regulations provides little incentive for weatherization and natural disaster protection. This unpreparedness is especially evident in Texas where the isolated state grid and extreme lack of grid regulations (perpetuated over decades) left millions without electricity and resulted in at least 194 people losing their lives (Schwartz et al. 2021; Despart et al. 2021). The lack of electricity and water hits communities of color hardest, while disaster aid disproportionately 
benefits affluent white communities (YanceyBragg and Jervis 2021).

Utility companies' excuses for not implementing more safety and weatherization measures usually focus on the uniqueness of each weather event and the supposed ineffectiveness and high costs associated with safety analyses. The main advantage of a free market for utility companies is that competition keeps prices generally low. Consumers can get very cheap rates via variable price options that depend on wholesale energy costs instead of having fixed cost rates. However, variable prices can result in predatory "emergency" price gouging which can make it harder for many Americans, especially BIPOC, to pay their energy bills and afford other necessities like food and shelter (Ingber 2018). In extreme cases like the February 2021 winter storm in Texas, price gouging resulted in thousand-dollar utility bills that practically bankrupted consumers (McDonnell et al. 2021).

Price gouging is an economic tactic that correlates with supply and demand. It ideally signals to consumers to reduce usage so that more people have access during crises. Some economists use this argument to defend price gouging and argue against price gouging laws that are in place to protect consumers (Carden 2019). However, this argument overlooks systemic racism and the need for environmental justice. Relying on price as an effective signal for resource conservation during emergencies results in wealthier people hoarding commodities and maintaining priority access to utilities like water and electricity. While price gouging laws are in place in thirty-nine states (including Texas) and several U.S. territories, these laws are inconsistent and oftentimes not effective, as seen in Texas in February of 2021 (Morton 2020).

The reality of climate change means extreme weather events are becoming more common, so catastrophes like the Texas winter storm will become more frequent (Kaplan 2020). To prepare for this reality, I propose instituting federally mandated price-gouging laws that prohibit predatory utility cost increases. The U.S. Department of Energy (DOE) has set a precedent for responding to price gouging during natural disasters following Hurricane Katrina in 2005 by investigating price gouging incidents (U.S. Secretary of Energy 2005). States should revise the variable versus fixed cost model. Additionally, to make electricity access more equitable, I propose federally mandated minimum natural disaster preparation, including electricity backup supplies (identified sources of emergency fuel, generators, etc.) and weatherization plant upgrades for extreme temperatures, wildfires, and flood preparation. Expanding electricity capabilities by investing in sustainable energy generation and storage technologies like fuel cells and batteries will better serve communities nationwide as well. Federal funding for power plant weatherization and disaster preparedness should be overseen by the DOE and can be funded by reallocated fossil fuel subsidies.

\section{ii. Recommendation 2: Household weatherization upgrades for equitable electricity access}

To make energy access equitable for all communities regardless of energy source, household utility infrastructures should be equal, and utility reliability should be standard. Black Americans and other people of color are more likely to have their utilities cut off, have less efficient household energy infrastructure, and face additional fees than white Americans (Kowalski 2020). In tandem with weatherization upgrades to utility plants, households with lower energy efficiency need to be upgraded. Some weatherization programs already exist including the DOE's Weatherization Assistance Program (WAP), established in 1976, which provides formula grants to all 50 states, the District of Columbia, Puerto Rico, Guam, Virgin Islands, American Samoa, Northern Mariana Islands, and Native American tribes (DOE n.d.). In 2010, the DOE invested $\$ 2$ billion in WAP with an additional $\$ 715$ million invested from other agencies. The weatherization upgrades saved households an average of $\$ 3,803$, including saving $\$ 223$ per year on energy as of 2010 (DOE 2015).

The individual and national economic fallout from the ongoing COVID-19 pandemic will take a long time to subside. As of early 2021, many people are still staying home, unemployment remains high, and national poverty has increased (Boghani 2020). As more Americans struggle to pay their 
bills and federal stimulus relief lags behind, the impact of energy poverty will be higher. The LowIncome Home Energy Assistance Program (LIHEAP) is a federal program that provides help with utility bills, weatherization, and other expenses ("LIHEAP" 2021). Additional federal assistance for LIHEAP, $\$ 900$ million, was included in the CARES act passed in July of 2020, which is in addition to the 2020 budget for LIHEAP of about $\$ 3.3$ billion (U.S. DH\&HS 2019). However, as of 2016, when LIHEAP had a similar budget, only $20 \%$ of eligible households could participate in the program due to insufficient funding (U.S. DH\&HS 2016).

To be eligible for WAP, a household must be at or below $200 \%$ of the federal poverty line, which is currently defined as a family of two making $\$ 17,420 /$ year (ASPE 2021). Other eligibility criteria include receiving supplemental security income or aid for dependents (DOE n.d.). While eligibility based on household income is important, the main determinant of energy poverty is the percentage of that household income that people and families pay for utilities. Low-income families pay from $8 \%$ to $17 \%$ of their income on utilities, while other households pay about 3\% (Bednar and Reames 2020; DOE n.d.).

I suggest modification of WAP to expand and redefine eligibility criteria to include and prioritize households that spend more than $7 \%$ of their income on utilities. Additionally, a current review of the program must be done to understand the expansion of the program from 2010 to 2021 . As of 2017 , the DOE reported spending about $\$ 2.1$ billion on WAP with $\$ 678$ million in additional investments from states and utilities (DOE 2019). This budget is not a significant increase from 2010 . Without knowledge of the current valuation and success of WAP, I suggest significantly increasing the investment to reach more households in need. There is precedent for a budget increase based on President Biden's commitment to ensure $40 \%$ of investments in renewable energy-related projects are directed to historically disadvantaged communities (The White House 2021). iii. Recommendation 3: Environmental Justice Task Forces to ensure equity in the renewable energy transition

The renewable energy transition has been in progress for decades, but many policies still attempt to make sweeping changes without considering the complex impacts on historically underserved communities, including BIPOC and low-income communities. For example, in 2020, California implemented a mandate that all new buildings must have solar panels, which made many new homes and apartments too expensive for people who are low-income (Chatlani 2019). Additionally, some proposed policies like cap-andtrade plans have not worked in California and have actually increased pollution in BIPOC and lowincome communities because companies offset their local emissions by reducing emissions elsewhere instead of improving the local air quality (Cushing et al. 2016). Cap-and-trade policies proposed for the Northeastern U.S. are expected to increase the price of gasoline, adding an additional burden on low-income households (Murphy 2020).

To more effectively incorporate environmental justice at the state and local level as part of the ongoing renewable energy transition, I propose the establishment of state-specific (or region-specific for U.S. territories, tribal nations, and District of Columbia) Environmental Justice Task Forces (EJTF) funded by the DOE. These task forces will allocate funding for renewable energy deployment in different parts of their region with a focus on funding the installation of renewable energy technologies (generation and storage) in and possibly transmission to BIPOC and low-income communities. The task forces would accept grant proposals from various local groups, including nonprofits, advocacy organizations, small renewable energy companies, or community groups for funding to install renewable energy technologies like solar cells. Funding would guarantee no upfront cost for consumers.

Having these task forces as a prerequisite for federal funds ensures that environmental justice is centered in all renewable technology implementation. These task forces would be made up of local experts in community development, local legislators, and community leaders. Their membership in the task force would be financially 
compensated as part of the federal funding per region. Measures would need to be implemented to ensure that renewable energy companies do not have more power or influence on these projects than community organizations. Adopting models similar to Illinois Solar For All (ISFA), which involves solar cell companies applying for the program and using funds to incentivize installation in low-income communities, would make sure the power remains in the hands of the communities (IPA n.d.). All project proposals must specify and guarantee that $80 \%$ of renewable energy installation will directly benefit low-income and BIPOC communities.

The EJTF program would complement many existing state policies and programs that aim to increase environmental justice efforts in renewable energy deployment. California was the first state to establish low-income solar cell deployment initiatives with its Single-Family Affordable Solar Homes (SASH) and Multifamily Affordable Solar Housing (MASH) programs in 2009 ("Low-Income Solar Policy Guide" 2016). These programs provided funds for eligible households to install solar cells on their homes with a budget from the state of over $\$ 200$ million. D.C. implemented a comprehensive low-income solar initiative called the Solar for All program in 2016 which folded in three main thrusts of solar deployment including single and multi-family homes, community solar, and job development. The multi-million-dollar program's goal is to deploy solar cells for 100,000 households by 2032 .

The EJTF program could complement existing efforts like these by providing federal funding for state programs and providing representation for diverse communities across states and regions. Colorado, Illinois, Massachusetts, New York, and New Hampshire have all instituted relatively successful community solar programs, which provide solar to people who may not be able to install solar panels on their roofs (like renters) ("Low-Income Solar Policy Guide" 2016; IPA n.d.).

Renewable energy technologies use fewer resources to operate than energy-intensive sources like coal. In 2013, Texas utility customers saved $\$ 736$ million in energy costs from using wind. Illinois consumers saved over $\$ 176$ million in 2011 from the use of renewable energy sources (McCormick 2015). To properly establish the EJTF program in all 50 states, U.S. territories, and Washington D.C., I suggest a federal budget of $\$ 3$ billion, similar but higher than the WAP budget, with state and regional budget allocations based on population with an emphasis on the proportion of state or regional residents who live at or below $200 \%$ of the poverty level and/or who suffer from energy poverty. This budget should be facilitated by the DOE and can be made possible through President Biden's $\$ 2$ trillion commitment to clean energy over four years (Glueck and Friedman 2021). The program should be evaluated externally on an annual basis and the budget should be increased based on these evaluations.

\section{Conclusion}

Environmental justice is critical to solving the climate crisis. Transitioning to renewable energy without considering equity will only further inequalities that plague our society. Climate change is already ravaging people's livelihoods as well as claiming lives every year. We still have a chance to preserve the planet for all members of future generations, but we have to act now. By reinforcing and supporting the renewable energy transition with rigorous and comprehensive weatherization and infrastructure upgrades for both utilities and households, we can improve energy equity across the country and mitigate severe consequences of climate change in the long term by prioritizing the needs of those on the frontline.

\section{References}

ASPE, U.S. 2021. "HHS Poverty Guidelines for 2021." U.S. Department of Health \& Human Services, Last Modified January 15, 2021. https://aspe.hhs.gov/poverty-guidelines.
Banerjee, Neela, Lisa Song, and David Hasemyer. 2015. "Exxon's Own Research Confirmed Fossil Fuels' Role in Global Warming Decades Ago." Inside Climate News, September 16, 2015. https://insideclimatenews.org/news/160920 15/exxons-own-research-confirmed-fossilfuels-role-in-global-warming/. 
Bednar, Dominic J. and Tony G. Reames. 2020. "Recognition of and response to energy poverty in the United States." Nature Energy 5 (6): 432439.

https://www.nature.com/articles/s41560020-0582-0.

Berardelli, Jeff. 2020. "How Joe Biden's climate plan compares to the Green New Deal." CBS News, October 5, 2020.

https://www.cbsnews.com/news/green-newdeal-joe-biden-climate-change-plan/.

Blinken, Antony J. 2021. "The United States Officially Rejoins the Paris Agreement." U.S. Department of State.

https://www.state.gov/the-united-statesofficially-rejoins-the-paris-agreement/.

Blunt, Katherine and Sarah McFarlane. 2020. "The New Green Energy Giants Challenging Exxon and BP." The Wall Street Journal, December 11, 2020.

https://www.wsj.com/articles/the-newgreen-energy-giants-challenging-exxon-andbp-meet-nextera-enel-11607696660.

Boghani, Priyanka. 2020. "How COVID Has Impacted Poverty in America." Frontline, December 8, 2020.

https://www.pbs.org/wgbh/frontline/article/ covid-poverty-america/.

Bush, Vannevar 1945. "Science, The Endless Frontier." United States Government Printing Office, Washington: Office of Scientific Research and Development.

https://www.nsf.gov/od/lpa/nsf50/vbush194 5.htm.

Carden, Art. 2019. "Price Gouging Laws Are Knowledge Embargoes That Should Be Repealed." Forbes, August 31, 2019.

https://www.forbes.com/sites/artcarden/201 9/08/31/price-gouging-laws-are-

knowledgeembargoes-that-should-berepealed/.

Chatlani, Shalina. 2019. "Will Low-Income Communities Be Left Out Of California's Clean Energy Transition?" KPBS, October 18, 2019. https://www.kpbs.org/news/2019/oct/18/wi ll-low-income-residents-diverse-communitiesbe-l/.

Cushing, Lara J., Madeline Wander, Rachel MorelloFrosch, Manuel Pastor, Allen Zhu, and James Sadd. 2016. "A Preliminary Environmental Equity Assessment of California's Cap-andtrade Program." USC Dornsife Program for Environmental and Regional Equity: University of Southern California, University of California, Berkeley, Occidental College Los Angeles. https://dornsife.usc.edu/PERE/enviro-equityCA-cap-trade.
Desilver, Drew. 2020. "Renewable energy is growing fast in the U.S., but fossil fuels still dominate." Pew Research, January 15, 2020. https://www.pewresearch.org/facttank/2020/01/15/renewable-energy-isgrowing-fast-in-the-u-s-but-fossil-fuels-stilldominate/.

Despart, Zach, Alejandro Serrano, Stephanie Lamm. 2021. "Analysis reveals nearly 200 died in Texas cold storm and blackouts, almost double the official count." Houston Chronicle, April 1, 2021.

https://www.houstonchronicle.com/news/ho uston-texas/houston/article/texas-coldstorm-200-died-analysis-winter-freeze16070470.php.

Drehobl, Ariel and Lauren Ross. 2016. "Lifting the High Energy Burden in America's Largest Cities: How Energy Efficiency Can Improve Low-Income and Underserved Communities." In Energy Efficiency For All. American Council for an Energy-Efficient Economy. https://www.aceee.org/press/2016/04/repor t-energy-burden-low-income.

EPA. 2021. "Environmental Justice." https://www.epa.gov/environmentaljustice.

Evans, Simon. 2020. "Solar is now 'cheapest electricity in history', confirms IEA." Carbon Brief Clear on Climate, October 13, 2020.

https://www.carbonbrief.org/solar-is-nowcheapest-electricity-in-history-confirms-iea.

Ferman, Mitchell. 2021. "Winter storm could cost Texas more money than any disaster in state history." The Texas Tribune, February 25, 2021. https://www.texastribune.org/2021/02/25/t exas-winter-storm-cost-budget/.

Fleischman, Lesley and Marcus Franklin. 2017. "Fumes Across the Fence-Line: The Health Impacts of Air Pollution from Oil \& Gas Facilities on African American Communities." edited by Katherine Taylor and Sarah Uhl: National Association for the Advancement of Colored People (NAACP) and Clean Air Task Force (CATF). https://www.catf.us/resource/fumes-acrossthe-fence-line/.

Franklin, Marcus, Caroline Kurtz, Mike Alksnis, Lorah Steichen, Chiquita Younger, and Jacqueline Patterson. 2017. "Lights Out in the Cold: Reforming Utility Shut-Off Policies as if Human Rights Matter." NAACP Environmental and Climate Justice Program. https://naacp.org/resources/lights-out-cold. 
Fulwood III, Sam. 2016. "The United States' History of Segregated Housing Continues to Limit Affordable Housing." Center for American Progress.

https://cdn.americanprogress.org/content/up loads/2016/12/13063403/SegregatedHousin gBrief3-PDF.pdf.

Glueck, Katie and Lisa Friedman. 2021. "Biden Announces \$2 Trillion Climate Plan." The New York Times, July 14, 2020.

https://www.nytimes.com/2020/07/14/us/p olitics/biden-climate-plan.html.

GRID Alternatives, Vote Solar, Center for Social Inclusion. 2016. "Low-Income Solar Policy Guide."

https://www.lowincomesolar.org/wpcontent/uploads/2016/03/Low-Income-SolarPolicy-Guide 3.11.16.pdf.

Hasemyer, David and John H. Cushman Jr. 2015. "Exxon Sowed Doubt About Climate Science for Decades by Stressing Uncertainty." Inside Climate News, October 22, 2015. https://insideclimatenews.org/news/221020 15/exxon-sowed-doubt-about-climate-sciencefor-decades-by-stressing-uncertainty/

History.com Editors. 2017. "Climate Change History." A\&E Television Networks, Last Modified November 20, 2020.

https://www.history.com/topics/naturaldisasters-and-environment/history-ofclimate-change.

Ingber, Sasha. 2018. "31 Percent Of U.S. Households Have Trouble Paying Energy Bills." National Public Radio, September 19, 2018. https://www.npr.org/2018/09/19/64963346 8/31-percent-of-u-s-households-have-troublepaying-energy-bills.

IPA. n.d. "Illinois Solar For All." Illinois Power Agency (IPA). https://www.illinoissfa.com/.

Jervis, Rick. 2021. "'Just crippling': Texans devastated by ice storm are now hunting empty shelves for food and water." USA Today, February 18, 2021. https://www.usatoday.com/story/news/natio n/2021/02/18/texas-ice-storm-poweroutage-food-water/4497383001/.

Kaplan, Sarah. 2020. "The undeniable link between weather disasters and climate change." The Washington Post, October 22, 2020. https://www.washingtonpost.com/climatesolutions/2020/10/22/climate-curiousdisasters-climate-change/.

Kowalski, Kathiann M. 2020. "Racial disparities persist in electric service. Is 'willful blindness' to blame?" Energy News Network, July 1, 2020. https://energynews.us/2020/07/01/racialdisparities-persist-in-electric-service-iswillful-blindness-to-blame/.
Lavelle, Marianne. 2019. "Former Exxon Scientists Tell Congress of Oil Giant's Climate Research Before Exxon Turned to Denial." Inside Climate News, October 24, 2019.

https://insideclimatenews.org/news/241020 19/exxon-scientists-climate-research-testifycongess-denial/.

Madrigal, Alexis C. 2014. "The Racist Housing Policy That Made Your Neighborhood." The Atlantic, May 22, 2014.

https://www.theatlantic.com/business/archiv e/2014/05/the-racist-housing-policy-thatmade-your-neighborhood/371439/.

McCormick, Katharine. 2015. "Bridging the Clean Energy Divide: Affordable Clean Energy Solutions for Today and Tomorrow." Natural Resources Defense Council (NRDC).

https://www.nrdc.org/sites/default/files/clea n-energy-benefits-vulnerable-commsreport.pdf.

McDonnell Nieto del Rio, Giulia, Nicholas BogelBurroughs, and Ivan Penn. 2021. "His Lights Stayed on During Texas' Storm. Now He Owes $\$ 16,752$." The New York Times, February 20, 2021.

https://www.nytimes.com/2021/02/20/us/te xas-storm-electric-bills.html.

Mock, Brentin. 2019. "Neighborhoods With More People of Color Pay Higher Energy Bills." Bloomberg CityLab, November 25, 2019. https://www.bloomberg.com/news/articles/2 019-11-25/why-white-households-pay-lessfor-utilities.

Morton, Heather. 2020. "Price Gouging State Statutes." National Conference of State Legislators (NCSL), Last modified May 17, 2021. https://www.ncsl.org/research/financialservices-and-commerce/price-gouging-statestatutes.aspx.

Murphy, Dan. 2021. "Renewables chief hails 'crucial' Biden climate agenda as administration plans massive energy overhaul." $C N B C$, January 26, 2021

https://www.cnbc.com/2021/01/25/renewab le-energy-chief-hails-crucial-biden-climatechange-plans-.html.

Murphy, Matt. 2020. "Study Points To Greater Gas Price Impacts From Transpo Pact." State House News Service, November 19, 2020. https://www.wbur.org/earthwhile/2020/11/ 19/tci-impact-study-tufts-carbon-emissionsgas-price.

Nature Energy. 2020. "Energy justice towards racial justice." Nature Energy 5 (8): 551-551. https://www.nature.com/articles/s41560020-00681-w. 
Ocasio-Cortez, Alexandria. 116th Congress. 2019. "Recognizing the duty of the Federal Government to create a Green New Deal." https://www.congress.gov/bill/116thcongress/house-resolution/109/text.

Parker, Kim, Juliana Menasce Horowitz, Anna Brown, Richard Fry, D'Vera Cohn, and Ruth Igielnik. 2018. "Demographic and economic trends in urban, suburban and rural communities." In What Unites and Divides Urban, Suburban and Rural Communities. Pew Research Center. https://www.pewresearch.org/socialtrends/2018/05/22/demographic-andeconomic-trends-in-urban-suburban-andrural-communities/.

Price, Asher and Bob Sechler. 2021. "Winter storm blackouts plagued Texas in 2011, too. Recommendations made afterward went unenforced." Austin American-Statesman, February 19, 2021.

https://www.usatoday.com/story/news/natio n/2021/02/18/state-energy-winterprotections-lacking-reports-havesuggested/4490501001/.

Schwartz, Jeremy, Kiah Collier, and Vianna Davila. 2021. "'Power companies get exactly what they want": How Texas repeatedly failed to protect its power grid against extreme weather." The Texas Tribune, February 22, 2021. https://www.texastribune.org/2021/02/22/t exas-power-grid-extreme-weather/.

Shields, Laura. 2021. "Bolstering Federal Energy Assistance and Weatherization With State Clean Energy Programs." National Conference of State Legislators (NCSL), Last modified January 11, 2021.

https://www.ncsl.org/research/energy/bolste ring-federal-energy-assistance-and-

weatherization-with-state-clean-energyprograms.aspx.

Skelton, Renee and Vernice Miller. 2016. "The Environmental Justice Movement." Natural Resources Defense Council, March 17, 2016. https://www.nrdc.org/stories/environmentaljustice-movement.

Sundback, Mark F., Bill Rappolt, and Andrew P. Mina. 2020. "Electricity regulation in the United States: overview." Sheppard Mullin LLP. Thomson Reuters Practical Law, July 1, 2020. https://content.next.westlaw.com/8-5255799? isplcus $=$ true \&transitionType $=$ Default $\& \mathrm{c}$

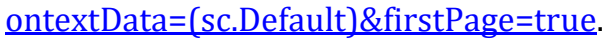

Thompson, Andrea. 2019. "Switching to Renewables Can Hurt Vulnerable Groups-Unless Utilities Plan Ahead." Scientific American, December 18, 2019.

https://www.scientificamerican.com/article/s witching-to-renewables-can-hurt-vulnerablegroups-unless-utilities-plan-ahead/.

UCS. 2002. "Public Utility Holding Company Act (PUHCA)." Last Modified October 26, 2002. https://www.ucsusa.org/resources/publicutility-holding-company-act.

UCS. 2019. "In the Northeast, Communities of Color Breathe 66\% More Air Pollution from Vehicles." Union of Concerned Scientists, June 27, 2019. https://www.ucsusa.org/about/news/commu nities-color-breathe-66-more-air-pollutionvehicles.

U.S. DH\&HS. 2016. "LIHEAP FAQs for Consumers." U.S. Department of Health \& Human Services. Administration for Children \& Families. Office of Community Services. https://www.acf.hhs.gov/ocs/faq/liheap-faqsconsumers.

U.S. DH\&HS. 2019. "LIHEAP DCL Funding Release FY20." U.S. Department of Health \& Human Services. Administration for Children \& Families. Office of Community https://www.acf.hhs.gov/ocs/grantfunding/liheap-dcl-funding-release-fy 20

U.S. DH\&HS. 2021. "Low Income Home Energy Assistance Program (LIHEAP)." Last Modified May 28, 2021.

https://www.acf.hhs.gov/ocs/low-incomehome-energy-assistance-program-liheap.

U.S. DOE. 2015. "Weatherization Assistance Program National Evaluations: Summary of Results." U.S. Department of Energy Office of Energy Efficiency \& Renewable Energy. https://www.energy.gov/sites/prod/files/201 5/08/f25/WAP NationalEvaluation WxWorks v14 blue 8\%205\%2015.pdf.

U.S. DOE. 2019. "Weatherization Works!". U.S. Department of Energy Office of Energy Efficiency \& Renewable Energy, Last Modified June 2019. https://www.energy.gov/sites/prod/files/201 9/07/f64/WAP-Fact-Sheet-2019.pdf.

U.S. DOE. n.d. "About the Weatherization Assistance Program." U.S. Department of Energy Office of Energy Efficiency \& Renewable Energy. https://www.energy.gov/eere/wap/aboutweatherization-assistance-program. 
U.S. EIA. 2021. "Summary of Legislation and Regulations Included in the Annual Energy Outlook 2021." Independent Statistics and Analysis, February 2021.

https://www.eia.gov/outlooks/aeo/assumptio ns/pdf/summary.pdf.

U.S. Secretary of Energy. 2005. "Fact Sheet: Department of Energy Response to Hurricane Katrina." U.S. Department of Energy.

https://www.energy.gov/sites/prod/files/edg Lmedia/KatrinaEnergyFactSheet.pdf.
The White House. 2021. "FACT SHEET: President Biden Takes Executive Actions to Tackle the Climate Crisis at Home and Abroad, Create Jobs, and Restore Scientific Integrity Across Federal Government."

https://www.whitehouse.gov/briefingroom/statements-releases/2021/01/27/factsheet-president-biden-takes-executiveactions-to-tackle-the-climate-crisis-at-homeand-abroad-create-jobs-and-restore-scientificintegrity-across-federal-government/.

Yancey-Bragg, N'dea and Rick Jervis. 2021. "Texas' winter storm could make life worse for Black and Latino families hit hard by power outages." USA Today, February 20, 2021. https://www.usatoday.com/story/news/natio $\underline{\mathrm{n} / 2021 / 02 / 20 / \text { texas-ice-storm-blackouts- }}$ minorities-hardest-hitrecovery/4507638001/.

Carolyn E. Ramírez is a Ph.D. candidate in chemical engineering at Northwestern University. Their research in Michael Wasielewski's lab focuses on identifying and characterizing unique organic semiconductors for use in solar cells. Carolyn is a founding member of their department's anti-racism, diversity, equity, and inclusion committee and a member of the Society for Advancement of Chicanos/Hispanics and Native Americans in Science (SACNAS). Carolyn is also involved in advocacy and mutual aid work on campus. She hopes to incorporate both policy work and science communication throughout her career.

\section{Acknowledgements}

C.E.R. would like to thank the Northwestern Science Policy Outreach Taskforce (SPOT) for support, revisions, and edits.

\section{Disclaimer}

The views expressed in this article are only those of the author and do not necessarily represent their department or university. 